\title{
PRODUCTIVITY AND VIRAL DISEASES OF SEED POTATOES DEPENDING ON THE PERIOD OF POTATO DESICCATION
}

\author{
Olga Vyshnevska $₫$ \\ olgavushnev@ukr.net \\ Volodymyr Dmytrenko ${ }^{1}$ \\ Nataliia Zakharchuk ${ }^{1}$ \\ Tetiana Oliinyk ${ }^{1}$ \\ ${ }^{1}$ Institute for Potato Research of National Academy of Agrarian Sciences of Ukraine \\ 22 Chkalova str. Nemishaieve, Borodianka distr., Kyiv region, 07853, Ukraine
}

$\triangle$ Corresponding author

\begin{abstract}
The aim of the research was to determine the crop productivity, yield of tubers of seed fraction and infection of basic potato seeds with viral infection depending on the period of potato desiccation, application of mineral oil Sunspray, the number and species of winged aphids in the Polissia region of Ukraine. The study was conducted in the prebasic seed production nursery garden of the Institute for Potato Research, NAAS under the conditions of spatial isolation from the main sources and vectors of viral infections of potatoes, located in Nemishaieve, Borodianka distr., Kyiv region in the southern part of the Polissia region of Ukraine. The subject of the research is pre-basic and basic seed material of potatoes of mid ripening varieties Myroslava, Predslava, Alians.

On average for 2018-2020 years of studies, the highest seed yield was obtained by potato desiccation 10 days after flowering of potatoes $-82.4-85.3 \%$.

However, the level of total and seed yields was low. The efficiency of seed potato production increased with the haulm removal after 20 days - with the total yield depending on the variety 20.6-30.0 t/ha, the yield of seed tubers was in the range of 20.6-22.9 $\mathrm{t} /$ ha with the seed content in the crop structure $-71.0-76.3 \%$. Late haulm removal - on $30^{\text {th }}$ and $40^{\text {th }}$ days after potatoes flowering caused an increase in the yield of tubers of non-standard fraction, with desiccation on $30^{\text {th }}$ day, the seed content in the crop decreased by $61.1-66.0 \%$, and with desiccation on $40^{\text {th }}$ - by $54-59.8 \%$. Thus, during the early haulm removal, part of the crop was lost, which during haulm removal in the late stages consisted of large tubers.

It has been found out, that potato plants, where the haulm removal during 2018, 2019 was carried out within 10 days after flowering, which was $4.0 \%$ (9.0\% for the check) for the Myroslav potato variety, $3.0 \%$ (10.0\% for the check) for the Predslava potato variety and $4.0 \%$ (9.0\% for the check) for the Alians potato variety were the least infected with $P V M$. The level of PVM infection when removing the haulm on the 10th day after flowering with the application of Sunspray mineral oil at a rate of $6.0 \mathrm{l} / \mathrm{ha}$ decreased on average for the three varieties by $1.5-2.5 \%$.

The best option to preserve the quality characteristics of seed potatoes was to desiccate the potato haulm on $20^{\text {th }}$ day after flowering of potato varieties Myroslava, Predslava and Alians and the application of mineral oil Sunspray -6.0 1/ha. The yield was 28.8-30.0 t/ha, seed fraction 20.6-22.9, seed yield - 71.0-76.3\%, viral PVM infection was $2.03 .0 \%$.

Keywords: potatoes, yield, structure, seed yield, desiccation, viruses, contamination, aphids, species of aphids, mineral oil.
\end{abstract}

DOI: 10.21303/2504-5695.2021.002067

\section{Introduction}

Potatoes belong to the crops that are largely affected by disease. Harmful viral diseases of potatoes are manifested in reduced yields, deteriorating marketability and product quality. Yield losses due to viral damage depend on the species and strains of pathogens common in this soil-cli- 
matic zone. Potato crop losses due to viral diseases in the Polissia region of Ukraine make on average 30-40\%, reaching 38-70\%. Damage from the PVM virus in Polissia can be more than $40 \%$ of the crop and increase with complex damage to plants by several pathogens. Most varieties are completely affected by $P V M$, due to which farms do not receive a significant part of the harvest each year [1].

One percent of plants, affected by severe viruses, causes a decrease in yield by $0.5-0.6 \%$ [2].

The existing system of virus-free potato seed production in Ukraine allows releasing seed material from the most harmful viruses ( $P V C, P V S, P V M, P V Y, P L R V)$. It is established, that the main source of re-infection is the presence in the plantations of plants-carriers with viral diseases, and the intensity of infection is provided by a large number of winged individuals of aphids. Moreover, the presence of a large number of species of aphids - $P V Y$ carriers causes the primary reinfection of healthy potato material with this virus [3].

In terms of the number and distribution of species that can transmit phytopathogenic viruses, aphids rank first among all vector insects. The main source of re-infection is the presence in the plantations of plants-carriers with viral diseases, and the intensity of infection is provided by a large number of winged individuals of aphids. Moreover, the presence of a large number of species of aphids - $P V Y$ carriers causes the primary reinfection of healthy potato material with this virus. The most important out of 25 species of aphids that carry potato viruses are Aphis fabae, Aphis nasturtii, Aphis frangulae Aphis gossypii, Myzus persicae, Aulacorthum solani, Macrosiphum euphorbiae) [4-6].

Basic seed potatoes have optimally early terms of destruction of potatoes to minimize the possibility of late infection of plants, to prevent the transition of infection in the tubers of a new crop. Haulm removal is carried out at the time of formation of seed tubers, which have a size not exceeding 28-45-60 $\mathrm{mm}$ in cross diameter in an amount not exceeding $70-80 \%$, in the crop structure.

The positive impact of this measure has been confirmed by the results of numerous studies. It is proved, that early removal of haulm significantly reduces the number of tubers, infected with viruses in the current year, due to the fact that some new lesions do not have time to penetrate the tubers of the new crop [7-10].

The probability of viral infection of plants decreases significantly with a decrease in the number of insects-carriers and their activity with the use of insecticides and mineral oils. Treatment of potato plants with $1 \%$ aqueous emulsion of mineral and vegetable oils every 7-10 days, starting from the period of full germination, allowed minimizing the level of infectious load and significantly limiting the number of new $P V Y$ infections in the cultivation of seed potatoes $[11,12]$.

Infection of potato plants with $P V Y$ in areas, treated with Superior 70 mineral oil, ranged from 2.1 to $12.2 \%$, and in the check areas - from 20.4 to $37.7 \%$ for three varieties of potatoes. In the case of the use of Vasil-Y mineral oil, PVY infection ranged from 2.1 to $26.5 \%$, and in the check areas from 49.9 to $85.7 \%$ for the three varieties. These data show that there was a significant reduction in the degree of potatoes contamination with $P V Y$ due to the introduction of mineral oils [13-15].

In the check areas without spraying, $P V Y$ spread to initially virus-free potato plants by $18 \%$ (2014) and $22 \%$ (2015), with a significant reduction in the prevalence of $P V Y$ when applying several treatments. The largest reduction in $P V Y$ infection, by only $4 \%$ (2014) and $12 \%$ (2015), was due to the combined treatment with mineral oils and insecticides, followed only by oil sprays; while sprays, containing only insecticides, did not significantly reduce the prevalence of $P V Y$.

Multiple logistic regression simulation confirmed the relative effectiveness of combining aerosol oils and insecticides to reduce the prevalence of $P V Y$, taking into account various inoculum and aphid factors. The simulation also emphasized the importance of primary seed planting with low infestation of potatoes with $P V Y$ and early application of leaf spraying [16-18].

The aim of the research was to determine the crop productivity, yield of tubers of seed fraction and infection of basic potato seeds with viral infection depending on the period of potato 
desiccation, application of mineral oil Sunspray, the number and species of winged aphids in the Polissia region of Ukraine.

\section{Materials and methods}

The research was carried out in the nursery of pre-potato seed production of the Institute of Potato NAAS in terms of spatial isolation from the main sources and carriers of viral infections of potatoes, located in Nemishaieve, Borodianka district, Kyiv region in the southern part of the Polissya zone of Ukraine.

Subject of research - pre-basic and basic seed material of potatoes of mid ripening varieties Myroslava, Predslava, Alians.

In 2018-2020, the haulm removal system was applied to the seed material of potato varieties in accordance with the experimental scheme:

1. Check (without haulm removal and aphicide -insecticidal treatments).

2. Haulm removal in 10 days after flowering+aphicide-insecticidal treatments.

3. Haulm removal in 20 days after flowering+aphicide-insecticidal treatments.

4. Haulm removal in 30 days after flowering+aphicide-insecticidal treatments.

5. Haulm removal in 40 days after flowering+aphicide-insecticidal treatments.

6. Haulm removal in 10 days after flowering+aphicide-insecticidal treatments+Sunspray.

7. Haulm removal in 20 days after flowering+aphicide-insecticidal treatments + Sunspray.

A disinfectant of planting tubers Seles Top, 0.5-0.7 1/t was used in all variants of the experiment to protect potatoes from the Colorado potato beetle and aphids.

During the growing season, in addition to the check, 8 treatments of potato plantations against aphids were carried out with drugs with aphicide action - Enzhio $247 \mathrm{SC}, 0.18$ 1/ha, Fastak, 0.07-0.10 1/ha, Karate-Zeon 050 EC, 0.1-0,2 1/ha, Danadim 40 \%+Fastak k.e., 2,0 1/ha+0.15 1/ha, Vantex, 0.07 1/ha, Proteus 110 OD, 0.75 1/ha. Mineral oil - Sunspray, 6 1/ha was applied 8 times, added to each aphicide-insecticide treatment. A desiccant Rehlon Super 150 SL, with a total rate of 21 /ha with the application in several stages - the first treatment of potatoes with a rate of $0.81 /$ ha, the second one $-1.2 \mathrm{l} / \mathrm{ha}$, was used to remove the haulm. Desiccation was combined with treatment of plants with Shyrlan 500 SC.

Haulm desiccation was carried out on July 27, continuing it every 10 days according to the experimental scheme.

The field experiment was established in accordance with the methodology of the experimental case [19].

Sod-medium-podzolic sandy soil with a humus content of $1.2-1.5 \%$, mobile forms of phosphorus 8.67-15.43 mg-eq per $100 \mathrm{~g}$ of soil, mobile potassium 6.7-9.4 mg-eq per $100 \mathrm{~g}$ of soil, $\mathrm{pH}$ of salt extract 5.9.

The area of the variant is $12.0 \mathrm{~m}^{2}$. Four times repetition. The scheme of potatoes planting $75 \times 20 \mathrm{~cm}$ at a density of planting -66.7 thousand pieces $/$ ha.

The growing technology is generally accepted for seed potato plantations in the Polissia region of Ukraine. Agricultural techniques of the field included technological operations: spring plowing, cultivation, formation of ridges with the help of a milling cultivator. The fertilizer system consisted of: application of mineral fertilizers in the form of nitroammophoska with a rate of $5 \mathrm{c} /$ ha in physical weight or $\mathrm{N}_{80} \mathrm{P}_{80} \mathrm{~K}_{80}$ in $\mathrm{kg}$ active ingredient/ha with their application locally in the furrows during potatoes planting.

The records of a crop are conducted from each plot, from each variant and repetition. Before the beginning of harvesting the full records of quantity of healthy and marked sick plants were carried out, places of possible exceptions were marked.

The structure of the crop was determined for all variants from the plots of the first and third repetitions, by sampling through weighing $10 \mathrm{~kg}$ by separating the tubers into fractions: up to $28 \mathrm{~mm}, 28-60 \mathrm{~mm}$, more than $60 \mathrm{~mm}$. The number of tubers of each fraction was counted, weighed and determined as a percentage of the total number or weight. The obtained yield data were converted into tons per hectare. 
The statistical processing of experimental data was performed using the computer program STATISTICA 6.0 [20].

The collection of aphids by the method of Merike traps and determination of their species was carried out according to the guidelines for insects-carriers of viral diseases of potato diseases [21].

The collection of aphids by the method of Merike traps was performed every one or two days, in the laboratory conditions, the calculation of winged individuals and their preservation with $75 \%$ ethyl alcohol for further identification of species was carried out. The content of viral infection in potato plants in the field was determined in the dynamics: in the germination phase, budding-flowering of potato plants and in the post-harvest period (tuber indexing method) [22].

The predicted viral load of the seed plot for aphid species potentially active in the spread of potato viruses was calculated using a scale of virus transmission indices according to [23]. The calculation was performed according to the recommendations [24]. To detect the content of viral infection, the method of solid-phase enzyme-linked immunosorbent assay (double sandwich variant, DAS-ELISA) [25] using commercial test systems from LOEWE, Germany, was applied. The reaction results were recorded by Termo Labsystems Opsis MR (USA) reader with Dunex Revelation Quicklink software at a wavelength of 405/630 nm. The processing of optical density data of the samples was performed by the method of descriptive statistics, determining the average and standard deviations of the data. The threshold value of the optical density, which distinguishes the positive results of the enzymatic reaction from the background value, was determined for each tablet separately and in accordance with the recommendations [25].

Aim of research. To develop and accomplish methods of protection of healthy seed potatoes from repeated infection by viruses in the Polissya zone of Ukraine.

Research tasks.

1. Determination of total yield/yield of seed fraction under different terms of haulm desiccation as well as under treatment with mineral oil "Sunspray".

2. Definition of species and number of flying aphids in the Polissya zone of Ukraine.

3. Determination of proportion of basic seeds, infected with main potato viruses.

\section{Results and discussion}

Meteorological conditions of the research years (2018-2020) were mainly arid and were characterized by a constant excess of average monthly air temperatures relative to the average longterm values, there was uneven precipitation.

Weather conditions in the growing seasons 2018 and 2019 were hot and dry and generally not appropriate for growth and development of potato plants. Mean monthly air temperatures in all months were much higher than climate data (April, May, June, July, August, and September were warmer than average by $5.6{ }^{\circ} \mathrm{C}, 4.6{ }^{\circ} \mathrm{C},+3.6{ }^{\circ} \mathrm{C},+3.0{ }^{\circ} \mathrm{C},+5.5{ }^{\circ} \mathrm{C},+2.3{ }^{\circ} \mathrm{C}$ respectively. Especially hot were April, May, August, accompanied by the lack of precipitation. For example, the precipitation in May was much lower than average climate data might suggest (39 vs. $60 \mathrm{~mm}$ ). At the same time, in June and July the amount of precipitation was close to average ( 80 and $85 \mathrm{~mm}$ respectively).

Weather conditions during the growth period of 2020 were suitable for growth and development in the first half of this period and adverse in the second. Mean monthly temperatures in April and May were lower than average, whereas in the following months they were higher by $4.5^{\circ} \mathrm{C}$, $2.6{ }^{\circ} \mathrm{C}, 4.9^{\circ} \mathrm{C}, 3.3{ }^{\circ} \mathrm{C}$ in June, July, August, and September respectively.

All months of this growth period with an exception of May (188 mm vs. $60 \mathrm{~mm}$ average) were characterized by the very pronounced lack of precipitation. In June, July, August, and September the amount of precipitation was $59 \mathrm{~mm}, 46 \mathrm{~mm}, 11 \mathrm{~mm}$ and $16 \mathrm{~mm}$ respectively $(21 \mathrm{~mm}$, $39 \mathrm{~mm}, 69 \mathrm{~mm}$, and $53 \mathrm{~mm}$ less than average). According to climate data, the mean amount of precipitation for the whole period April-September is $432 \mathrm{~mm}$. This is much more humid compared to the season 2020 (343 $\mathrm{mm}$ or $89 \mathrm{~mm}$ less than average). 
The growth and development of plants of three potato varieties - Myroslava, Predslava, Alians in 2018-2019 research years corresponded to their maturity. The density of stems in the research years varied between 237-340 thousand pieces per 1 hectare.

On average for 2018-2020 years of studies, the highest seed yield was obtained by potato desiccation 10 days after flowering of potatoes $-82.4-85.3 \%$ (Table 1).

Table 1

Potato yield and yield of tubers of seed fraction depending on the terms of haulm removal, 2018-2020

\begin{tabular}{|c|c|c|c|c|c|c|c|c|c|}
\hline \multirow{2}{*}{ Experiment options } & \multicolumn{3}{|c|}{ Myroslava } & \multicolumn{3}{|c|}{ Predslava } & \multicolumn{3}{|c|}{ Alians } \\
\hline & t/ha & t/ha & $\%$ & t/ha & t/ha & $\%$ & t/ha & t/ha & $\%$ \\
\hline $\begin{array}{l}\text { Check (without haulm } \\
\text { removal) }\end{array}$ & 46.7 & 22.2 & 44.5 & 42.9 & 20.6 & 48.0 & 42.1 & 20.7 & 44.2 \\
\hline $\begin{array}{l}\text { haulm removal in } 10 \\
\text { days after flowering }\end{array}$ & 19.0 & 16.2 & 85.3 & 18.2 & 15.0 & 82.4 & 18.3 & 15.3 & 83.6 \\
\hline in 20 days & 30.0 & 22.9 & 76.3 & 28.8 & 21.2 & 73.6 & 29.0 & 20.6 & 71.0 \\
\hline in 30 days & 33.6 & 21.8 & 64.9 & 32.4 & 21.4 & 66.0 & 34.2 & 20.9 & 61.1 \\
\hline in 40 days & 43.3 & 23.4 & 54.0 & 36.9 & 22.1 & 59.8 & 37.8 & 21.3 & 56.3 \\
\hline $\begin{array}{l}\text { haulm removal in } 10 \text { days } \\
\text { after flowering+Sun- } \\
\text { spray }-6.01 / \text { ha }\end{array}$ & 24.6 & 19.3 & 78.5 & 21.1 & 17.8 & 84.4 & 22.6 & 18.0 & 74.6 \\
\hline $\begin{array}{l}\text { haulm removal in } 10 \text { days } \\
\text { after flowering+Sun- } \\
\text { spray }-6.01 / \text { ha }\end{array}$ & 29.8 & 21.9 & 74.2 & 30.9 & 21.8 & 70.6 & 30.6 & 21.9 & 71.6 \\
\hline $\mathrm{LSD}_{05}$ & $2.2-1.4$ & $0.9-0.8$ & - & $2.4-2.0$ & $0.77-0.67$ & - & $2.0-1.9$ & $0.7-0.65$ & - \\
\hline
\end{tabular}

However, the level of total and seed yields was low. The efficiency of seed potato production increased with the haulm removal after 20 days - with the total yield depending on the variety 20.6-30.0 t/ha, the yield of seed tubers was in the range of 20.6-22.9 t/ha with the seed content in the crop structure $-71.0-76.3 \%$. The late haulm removal - on $30^{\text {th }}$ and $40^{\text {th }}$ days after potatoes flowering caused an increase in the yield of tubers of non-standard fraction, with desiccation on $30^{\text {th }}$ day, the seed content in the crop decreased by $61.1-66.0 \%$, and with desiccation on $40^{\text {th }}-$ by $54-59.8 \%$. Thus, during the early haulm removal, part of the crop was lost, which during the haulm removal in the late stages consisted of large tubers.

Weather conditions in 2018 were favourable for the development of aphids. The number of winged aphids-carriers of potato viruses, which fell into one trap for the entire growing season, was 1042.5 pieces.

Monitoring of the growth of the number of winged aphids in the southern part of the Polissia zone in 2018 showed that the growth of their number was observed in the period from the second decade of June to the third decade of July with a high number of individuals per trap - on average in June caught -285.5 individuals/trap, July 525.5 individuals. The highest number of aphids in June was observed in the third decade - 192 pieces/trap, in July - in the second decade - 432 pieces/trap, Fig. 1. "Critical threshold" of aphid damage (50 points) was observed 8 days after the flowering phase of plants.

During the 2019 growing season, the number of winged carriers was 493 per Merike trap. The largest number of aphids in June was observed in the first decade - 125 pieces/trap, in July in the third decade - 141.5 pieces/trap, Fig. 1. The peak increase in the number of insects was observed from 10 to 14 July, with an average of 45 aphids per trap. The onset of a "critical period" of aphid infestation in 2019 , equal to 50 points, was not observed.

The monitoring of the growth of the number of winged aphids in 2020 showed what was observed in the conditions of the southern part of the Polissia zone during this period in the first and third decades of June (68 and 77.5 insects per decade/cup, respectively). The increase in the 
number of aphids was not observed as in previous years in early July. July and August were marked by low levels of potato virus carriers. The main dates of growth of the number of aphids were: May 31 - 44.0 individuals per trap, June $3-48.0$, June $10-31.0$, July $22-39.0$, July $29-48.5$, July $31-34$ individuals per trap.

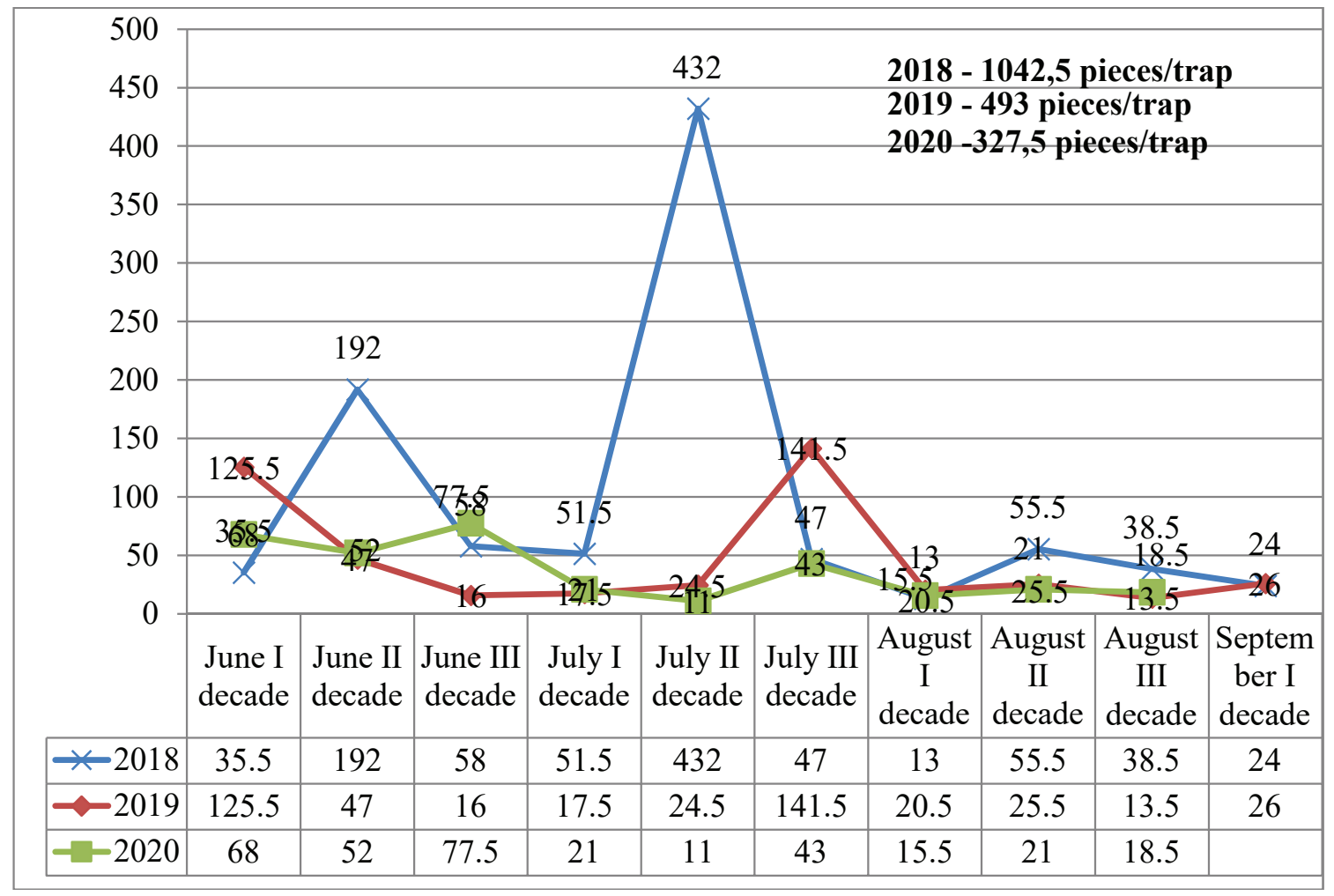

Fig. 1. Dynamics of growth of the number of winged aphids in plantations of basic seed potatoes in the zone of the southern part of Polissia of Ukraine (Kyiv region)

The number of aphid populations, their species composition, intensity and duration of flight in 2020 correspond to the low degree of entomological background of potato viral disease carriers, but the increase in the number of winged forms of aphids was the most susceptible to virus re-infection growth phase. This can cause possible infections and penetration of entomophilic viruses into the tubers, during this period there is an outflow of photosynthesis products from the leaves to the tubers and with the movement of nutrients viruses may enter the tubers.

According to the results of three-year observations on the development of the population of winged aphids in potato plantations in the southern part of Polissia of Ukraine (Kyiv region) it is established, that "critical periods" of virus carriers occurred in the period from the first decade of June to the third decade of July.

The largest total number of aphids was observed in 2018 - 1,042 pieces per Merike trap, including 525 pieces of potato virus carriers. The aggregate index of harmfulness of PVY and PLRV transmission was 118 points and is high, Table 2.

In 2019, the entomological background of PVY and PLRV transfer vectors was average, 493 aphids were trapped, including 263 aphids-carriers of potato viruses. Aphis fabae, Aulacorthum solani, Macrosiphum euphorbiae, Aphis nasturtii, Myzus persicae created a significant vector load on the experimental site. The aggregate vector index was 57.38 points. The vector load of the experimental field in 2020 was characterized as low, a total of 327.5 aphids were caught, including 160.0 vector carriers of potato viruses. The aggregate index of aphid harmfulness in potato plantations was 28.67 points. 
Table 2

Vector load of the experimental field (potato plantings), 2018-2020.

$\begin{array}{cccc}\text { Type of aphids } & \begin{array}{c}\text { Aggregate vector } \\ \text { load index, 2018 }\end{array} & \begin{array}{c}\text { Aggregate vector } \\ \text { load index, 2019 }\end{array} & \begin{array}{c}\text { Aggregate vector } \\ \text { load index, 2020 }\end{array} \\ \text { Aphis fabae } & 28.9 & 11.7 & 11.5 \\ \text { Aphis frangulae } & 24.38 & 8.48 & 4.77 \\ \text { Aphis gossypii } & 18.0 & 7.5 & 2.0 \\ \text { Aphis nasturtii } & 20.0 & 8.8 & 3.2 \\ \text { Macrosiphum euphorbiae } & 3.0 & 7.0 & 2.4 \\ \text { Myzus persicae } & 9.0 & 9.0 & 4.0 \\ \text { Aulacorthum solani } & 8.0 & 4.9 & 0.8 \\ \text { Total aphids, pcs. } & 1042.5 & 493.0 & 327.5 \\ \text { Aggregate index } & 525.0 & 263.0 & 160.0\end{array}$

According to the results of post-harvest testing by indexation method with subsequent testing by DAS-ELISA in 2019, the dependence of the level of infestation of potato plants with PVM depending on the timing of haulm removal in combination with aphicide-insecticide treatments and application of mineral oil has been established, Table 3 .

Table 3

The degree of infection of seed potatoes with latent infection with PVM, PVY, PLRV according to the results of post-harvest testing by DAS-ELISA, 2019

\begin{tabular}{|c|c|c|c|c|}
\hline & Experiment options & $P V M$ & $P V Y$ & PLRV \\
\hline \multicolumn{5}{|c|}{ Myroslava variety } \\
\hline 1 & Check (without haulm removal) & 9.0 & - & - \\
\hline 2 & Haulm removal in 10 days after flowering & 4.0 & - & - \\
\hline 3 & -II- in 20 days after flowering & 4.0 & - & - \\
\hline 4 & -II- in 30 days after flowering & 6.0 & - & - \\
\hline 5 & - II- in 40 days after flowering & 8.5 & - & - \\
\hline 6 & in 10 days after flowering+Sunspray $-6,01 /$ ha & 2.0 & - & - \\
\hline 7 & in 20 days after flowering+Sunspray $-6,01 /$ ha & 2.5 & - & - \\
\hline \multicolumn{5}{|c|}{ Predslava variety } \\
\hline 1 & Check (without haulm removal) & 10.0 & - & - \\
\hline 2 & Haulm removal in 10 days after flowering & 3.0 & - & - \\
\hline 3 & -II- in 20 days after flowering & 4.0 & - & - \\
\hline 4 & -II- in 30 days after flowering & 5.0 & - & - \\
\hline 5 & - II- in 40 days after flowering & 9.5 & - & - \\
\hline 6 & in 10 days after flowering+Sunspray $-6,0 \mathrm{l} / \mathrm{ha}$ & 1.5 & - & - \\
\hline 7 & in 20 days after flowering+Sunspray $-6,01 /$ ha & 2.0 & - & - \\
\hline \multicolumn{5}{|c|}{ Alians variety } \\
\hline 1 & Check (without haulm removal) & 9.0 & - & - \\
\hline 2 & Haulm removal in 10 days after flowering & 4.0 & - & - \\
\hline 3 & -II- in 20 days after flowering & 4.0 & - & - \\
\hline 4 & -II- in 30 days after flowering & 6.0 & - & - \\
\hline 5 & $-\mathrm{II}-$ in 40 days after flowering & 9.0 & - & - \\
\hline 6 & in 10 days after flowering+Sunspray $-6,01 /$ ha & 2.5 & - & - \\
\hline 7 & n 20 days after flowering+Sunspray $-6,01 /$ ha & 3.0 & - & - \\
\hline
\end{tabular}

It has been found out, that potato plants, where the haulm removal during 2018, 2019 was carried out within 10 days after flowering, which was $4.0 \%$ (9.0 \% for the check) for the Myroslav 
potato variety, $3.0 \%$ (10.0 \% for the check) for the Predslava potato variety and $4.0 \%(9.0 \%$ for the check) for the Alians potato variety were the least infected with PVM. The level of PVM infection when removing the haulm on the 10th day after flowering with the application of Sunspray mineral oil at a rate of $6.01 /$ ha decreased on average for the three varieties by $1.5-2.5 \%$. In 2019, no infected PVY and PLRV potato plants were detected.

The removal of potato haulm in 30 days after flowering of potatoes provided the following degree of PVM infection of seed potatoes: Myroslava variety $-6.0 \%$ (the control variant without potato haulm removal $-9.0 \%$ ), Predslava variety $-5.0 \%$ (the control variant without potato haulm removal $-10.0 \%$ ), Alians variety $-6.0 \%$ (the control variant without potato haulm removal $-9.0 \%$ ).

\section{Conclusions}

In the course of the research it was found, that the best option to preserve the quality characteristics of seed potatoes was to desiccate potato haulm on $20^{\text {th }}$ day after flowering of potato varieties Myroslava, Predslava and Alians and the application of mineral oil Sunspray $6.0 \mathrm{l} / \mathrm{ha}$. The yield was $28.8-30.0 \mathrm{t} / \mathrm{ha}$, seed fraction $20.6-22.9$, seed yield $-71.0-76.3 \%$, viral $P V M$ infection was $2.03 .0 \%$, which corresponds to the requirements of the normative document - "Methodological requirements in the field of seed production to preserve the varietal and sowing qualities of seed potatoes", the order of the Ministry of Agrarian Policy and Food of Ukraine No. 384 of 12.07.2019.

Due to climate changes it could be difficult to diminish the effects of the process of haulm degeneration in the second half of vegetation. This process could be stopped by proper irrigation.

It could be helpful to determine the content of $P V M$ and $P V Y$ in aphids. These studies require professionalism and training

In the near future, the economic efficiency of the studied methods for protection of seed potatoes from repeated viral infection will be determined by growing obtained seed under standard conditions (haulm destruction 14 days before harvest).

In addition, we are going to study the effects of application of mineral oils of different chemical composition under the extended spectrum of cultivars.

\section{References}

[1] Dmitruk, O. O., Derevianko, S. V., Reshotko, L. M., Volkova, I. V., Kucheriavenko, O. O., Bova, T. O., Zhenghua, Z. (2016). Phytovirus monitoring at the potato fields in chernihiv region agrocenoses. Agriciltural Microbiology, 23, 36-41. Available at: https://smic.in.ua/index.php/journal/article/view/126

[2] Rusetskiy, N. V. Blotskaya, Zh. V., Schaslenyuk, E. M. (2000). Izuchenie ustoychivosti mezhvidovyh gibridov kartofelya k virusnym boleznyam. Sbornik nauch. tr. RUP Nauchno-prakticheskiy tsentr NAN Belarusi po kartofelevodstvu i plodoovoschevodstvu, 10, 93-99.

[3] Zamalieva, F., Zharehina, T., Safiullina, G. (2019). Influence of biologically active preparations, fertilizer compositions, irrigation on the distribution of potato tuber diseases. Vestnik of Kazan State Agrarian University, 14 (3), 25-30. doi: https://doi.org/10.12737/article_5db851f1e7ef85.29058201

[4] Bondarchuk, A., Vyshnevska, O., Dmytrenko, V., Riazantsev, M. (2020). Results of vectors' monitoring, measures to combat viral diseases of potatoes in the area of the Ukraine's Polissia. Foothill and Mountain Agriculture and Stockbreeding, 67 (2), 8-28. doi: https://doi.org/10.32636/01308521.2020-(67)-2-1

[5] Taran, O. P., Mischenko, L. T., Orlovska, G. M., Chumak, V. O., Vishnevska, O. V. (2015). Species of viruses and vector pressure in evaluation phytosanitary condition of the forests potato. Naukovi dopovidi Natsionalnoho universytetu bioresursiv $i$ pryrodokorystuvannia Ukrainy, 5. Available at: http://nbuv.gov.ua/UJRN/Nd_2015_5_3

[6] Gerieva, F. T., Bolieva, Z. A., Basiev, S. S. (2014). Tli - perenoschiki virusnoy infektsii semennogo kartofelya na Severnom Kavkaze. Zaschita i karantin rasteniy, 12, 18-19.

[7] Chehalkova, L. K., Konova, A. M., Gavrilova, A. Y., Novikov, V. M. (2019). Features of the agrotechnology of early ripe grades of potatoes at cultivation on the seed purposes in conditions of the smolensk region. Vegetable Crops of Russia, 3, 99-103. doi: https://doi.org/10.18619/2072-9146-2019-3-99-103

[8] Semenchuk, V. G., Kolenchuk, M. N., Makoviychuk, S. D. (2018). Effect of potato tops extraction terms on seed potatoes productivity. Potato-growing, 26, 302-307. 
[9] Vyshnevska, O. V., Kostianets, M. I., Stoliarchuk, L. V., Shmun, S. A. (2017). Vplyv riznykh strokiv desykatsiyi kartoplynnia na nasinnievu produktyvnist ta urazhennist virusnymy infektsiyamy ozdorovlenoho nasinnievoho materialu kartopli v umovakh pivdennoho Polissia Ukrainy. Kartopliarstvo Ukrainy, 1-2 (42-43), 22-28.

[10] Anisimov, B. V., Yurlova, S. M. (2011). Fully to use environment improving and protecting methods of seed potato growing. Kartofel' i ovoschi, 2, 18-19.

[11] Anisimov, B. V., Blinkov, E. G., Yurlova, S. M. (2013). Mineral'nye i rastitel'nye masla dlya zaschity semennyh posadok kartofelya ot virusov. Zaschita i karantin rasteniy, 11, 27-28.

[12] Wróbel, S. (2014). Efficacy of Mineral Oil-Insecticide Mixtures for Protection of Potato Tubers Against PVY and PVM. American Journal of Potato Research, 91 (6), 706-713. doi: https://doi.org/10.1007/s12230-014-9403-y

[13] Fageria, M. S., Boquel, S., Leclair, G., Pelletier, Y. (2014). The Use of Mineral Oil in Potato Protection: Dynamics in the Plant and Effect on Potato Virus Y Spread. American Journal of Potato Research, 91 (5), 476-484. doi: https://oi.org/10.1007/ s12230-014-9377-9

[14] Boiteau, G., Singh, M., Lavoie, J. (2008). Crop border and mineral oil sprays used in combination as physical control methods of the aphid-transmitted potato virus Y in potato. Pest Management Science, 65 (3), 255-259. doi: https://doi.org/10.1002/ ps.1679

[15] Galimberti, A., Alyokhin, A. (2018). Lethal and Sublethal Effects of Mineral Oil on Potato Pests. Journal of Economic Entomology, 111 (3), 1261-1267. doi: https://doi.org/10.1093/jee/toy046

[16] MacKenzie, T. D. B., Nie, X., Singh, M. (2016). Crop Management Practices and Reduction of On-Farm Spread of Potato virus Y: a 5-Year Study in Commercial Potato Fields in New Brunswick, Canada. American Journal of Potato Research, 93 (6), 552-563. doi: https://doi.org/10.1007/s12230-016-9534-4

[17] MacKenzie, T. D. B., Lavoie, J., Nie, X., Singh, M. (2016). Effectiveness of Combined Use of Mineral Oil and Insecticide Spray in Reducing Potato Virus Y (PVY) Spread under Field Conditions in New Brunswick, Canada. American Journal of Potato Research, 94 (1), 70-80. doi: https://doi.org/10.1007/s12230-016-9550-4

[18] MacKenzie, T. D. B., Nie, X., Singh, M. (2021). Epidemiology and Management of Potato Virus Y. Emerging Trends in Plant Pathology, 113-140. doi: https://doi.org/10.1007/978-981-15-6275-4_6

[19] Bondarchuk, A. A., Koltunov, V. A., Oliynyk, T. M. et. al.; Bondarchuk, A. A., Koltunov, V. A. (Eds.) (2019). Kartopliarstvo: Metodyka doslidnoi spravy. Vinnytsia: TOV «TVORY», 652. Available at: https://ikar.in.ua/wp-content/uploads/2021/03/ Metodyka-dosl-sprav-kartop-1.pdf

[20] Ermantraut, E. R., Prysiazhniuk, O. I., Shevchenko, L. I. (2007). Statystychnyi analiz ahronomichnykh doslidnykh danykh v paketi STATISTICA 6.0. Kyiv: Polihraf Konsaltynh, 55.

[21] Banadysev, S. A., Yaschenko, N. P., Malinovskiy, S. V., Dudarevich, V. I. (2000). Metodicheskie ukazaniya po uchetu nasekomyh-perenoschikov virusnyh bolezney kartofelya. Minsk: Samohvalovichi, 34.

[22] Shpaar, D., Bykin, A., Dreger, D.; Shpaar, D. (Ed.) (2004). Kartofel’. Torzhok: OOO «Variant», 465.

[23] PVY vectors. Available at: https://aphmon.fera.co.uk/pvy_vector_info.cfm

[24] Vector pressure index. Available at: https://aphmon.fera.co.uk/vp_index.cfm

[25] Technical Information. ELISA Data Analysis. Version: 4 - 11.07.2014. Available at: https://www.bioreba.ch/saas/CustomUploa d/374O357O340O370O356O369O350O3210360O366O369O356O353O352O350O320O326O/ELISA_Data_Analysis.pdf

Received date 13.08.2021

Accepted date 21.09.2021

Published date 30.09.2021
(C) The Author(s) 2021

This is an open access article under the Creative Commons CC BY license

How to cite: Vyshnevska, O., Dmytrenko, V., Zakharchuk, N. (2021). Productivity and viral diseases of seed potatoes depending on the period of potato desiccation. EUREKA: Life Sciences, 5, 26-34. doi: https://doi.org/10.21303/2504-5695.2021.002067 